\title{
Determinants of native avian richness in suburban remnant vegetation: Implications for conservation planning
}

\author{
Grant C. Palmer ${ }^{a, b}$, James A. Fitzsimons ${ }^{a, 1}$, Mark J. Antos ${ }^{a, 2}$, John G. White $e^{a, *}$ \\ ${ }^{a}$ School of Life and Environmental Sciences, Deakin University, 221 Burwood Highway, Burwood, Victoria 3125, Australia \\ ${ }^{\mathrm{b}}$ Centre for Environmental Management, School of Science and Engineering, University of Ballarat, P.O. Box 663, Ballarat, \\ Victoria 3353, Australia
}

\section{Introduction}

In recent decades, the impacts of urbanization have been rec ognized as a key threat to many natural ecosystems around the world (e.g. Rottenborn, 1999; Eppink et al., 2004). Urbani zation results in fundamental changes to landscape composi tion and configuration with significant impacts upon the fauna and flora living within urban landscapes (Cornelis and Hermy, 2004; Clergeau et al., 2006a). These changes can either occur in landscapes that were already substantially modified (e.g. agricultural areas) and also areas that were rel atively natural (e.g. forests and woodlands). While some ur ban areas are likely to represent highly simplified and homogenous landscapes (e.g. inner city areas (Fernández Juricic, 2000)), other urban areas can be viewed as variegated landscapes (cf. Ford and Barrett, 1995; McIntyre and Hobbs,

\footnotetext{
* Corresponding author: Tel.: +61 413454 338; fax: +61 392517626.

E mail addresses: g.palmer@ballarat.edu.au (G.C. Palmer), james.fitzsimons@deakin.edu.au (J.A. Fitzsimons), mantos@parks.vic. gov.au (M.J. Antos), john.white@deakin.edu.au (J.G. White).

1 Present address: The Nature Conservancy, Suite 3.04, 60 Leicester Street, Carlton, Victoria 3053, Australia.

2 Present address: Research Branch, Parks Victoria, Level 10, 535 Bourke Street, Melbourne, Victoria 3000, Australia.
} 
1999) which are complex in structure, being comprised of integrated zones of residential development, industrial areas, remnant native vegetation patches and corridors, and open space. The pattern of urban landscapes (i.e. landscape com position and configuration) is expected to have a strong influ ence on the ability of wildlife to persist in urban areas (e.g. Dunford and Freemark, 2004; Platt and Lill, 2006; White et al., 2005; Pidgeon et al., 2007). While urban areas are increasingly recognized as having potential value for biodiver sity conservation (Fernández Juricic and Jokimäki, 2001; Bry ant, 2006; Pacheco and Vasconcelos, 2006), the relationship between biodiversity and the structure and configuration of the urban landscape is poorly understood.

Most recent research examining the influence of urbaniza tion on biodiversity has utilized birds as a model group (see Chance and Walsh, 2006). Several common themes have sub sequently emerged from this research largely relating to the simplification and change in avian community structure gen erally referred to as biotic homogenisation (e.g. Clergeau et al., 2006b). Species common in urban landscapes tend to be either exotic invaders or generalist native species that are tolerant of a wide variety of urban conditions (e.g. White et al., 2005; Antos et al., 2006; McKinney, 2006). Urban environ ments also often exhibit a high abundance of birds, but this can be tempered by low species richness, particularly of indigenous native species. Within urban environments, patches of remnant vegetation have been demonstrated to support a greater species richness and abundance of birds compared to surrounding residential areas (Fernández Juricic and Jokimäki, 2001; White et al., 2005). Of particular impor tance are patches of remnant vegetation, which appear to be critical for maintaining assemblages of indigenous birds in urban areas (Catterall et al., 1991; Recher, 2004; White et al., 2005).

One of the major issues for urban planning and conserva tion managers alike is a general paucity of ecological informa tion to inform sound planning decisions. McKinney (2006) highlights the need to develop strategies to preserve indige nous species in urbanized landscapes. To develop such strat egies we need an improved understanding of how indigenous species respond to urbanization processes and of the drivers of the distribution of indigenous species (Whited et al., 2000).

Remnant indigenous vegetation offers the best starting point to conserve native bird communities in urban environ ments, but even in remnant vegetation there are considerable differences in the representation of indigenous species (e.g. White et al., 2005; Jokimäki, 1999; Tilghman, 1987). What, therefore, drives native species composition in urban rem nant vegetation? Are the responses of different types of spe cies different? And how can this information be used to better plan urban environments to maintain maximum na tive species richness? We examine the major determinants of native bird species presence and richness in native vegeta tion remnants in urbanized environments in Melbourne, Aus tralia. Specifically, we aim to determine whether remnant size is the major determinant of species diversity or whether other habitat or landscape variables, such as vegetation structure and extent of surrounding vegetation, are also important. The responses of ecological groups of birds (based on habitat preference, foraging strata and life history attributes) to these landscape and habitat variables are examined. Recommenda tions to help urban planners maintain and enhance native bird species richness in urban environments are provided.

\section{Methods}

\subsection{Study area}

Research was conducted within the metropolitan region of Melbourne, Australia $\left(37^{\circ} 50^{\prime} \mathrm{S}, 44^{\circ} 58^{\prime} \mathrm{E}\right)$, which has a human population of around 3.5 million. Despite this large popula tion, housing density is low medium (population density 468 persons $/ \mathrm{km}^{2}$ in 2004; ABS, 2006), and consequently a large urban sprawl has developed. Significant increases in the number of multi unit dwellings have occurred in recent years and consequently housing density is increasing (Buxton and Tieman, 2005). A wide range of natural vegetation types oc curred prior to settlement including forests, woodlands, heathlands, wetlands and grasslands. Remnants of many of these habitats may still be found within parks and reserves embedded in the urban matrix. We define the 'urban matrix' as all areas of the urban environment that are not patches of remnant vegetation. The urban matrix, therefore, includes residential housing (both single and multi unit dwellings), industrial areas and urban infrastructure such as streets, community facilities and open space (e.g. golf courses, sports grounds). We focused our study only on indigenous woodland vegetation (i.e. vegetation dominated by trees) which is the dominant type of vegetation, remaining mostly in sites man aged to retain this vegetation and which receive only low pas sive recreational use. Other non woodland vegetation types in the Melbourne area such as heaths, grasslands and wet lands tend to support different bird communities and would not have been comparable with woodland vegetation. All study sites were dominated by evergreen species (mainly of the genus Eucalyptus although the genera Acacia, Leptosper mum and Melaleuca occurred as co dominants in some areas) and consisted of original native vegetation that had not been cleared. A few of the study sites also contained areas of re planted indigenous vegetation, but none were dominated by it. All study sites were located within the Gippsland Plain bio region, in the eastern and southeastern suburbs, within a $30 \mathrm{~km}$ radius of the Melbourne Central Business District.

Remnants were selected based on size and availability. Remnants were divided into three size classes small (1 $5 \mathrm{ha}$ ) ( $n$ 15), medium (6 $15 \mathrm{ha}$ ) (n 14) and large (>15 ha) (n 10). All sites were at least $2 \mathrm{~km}$ apart to improve their spa tial independence (Fig. 1).

\subsection{Bird surveys}

One hectare transects $(200 \mathrm{~m} \times 50 \mathrm{~m})$ were used to assess the avian species richness of each remnant. The number of tran sects at a site was stratified according to remnant size; one transect was used to survey small remnants, two transects were used in medium remnants and three transects were used in large remnants. Multiple transects were used because we were investigating richness at the remnant level and not the transect level per se. Multiple transects also helped to 


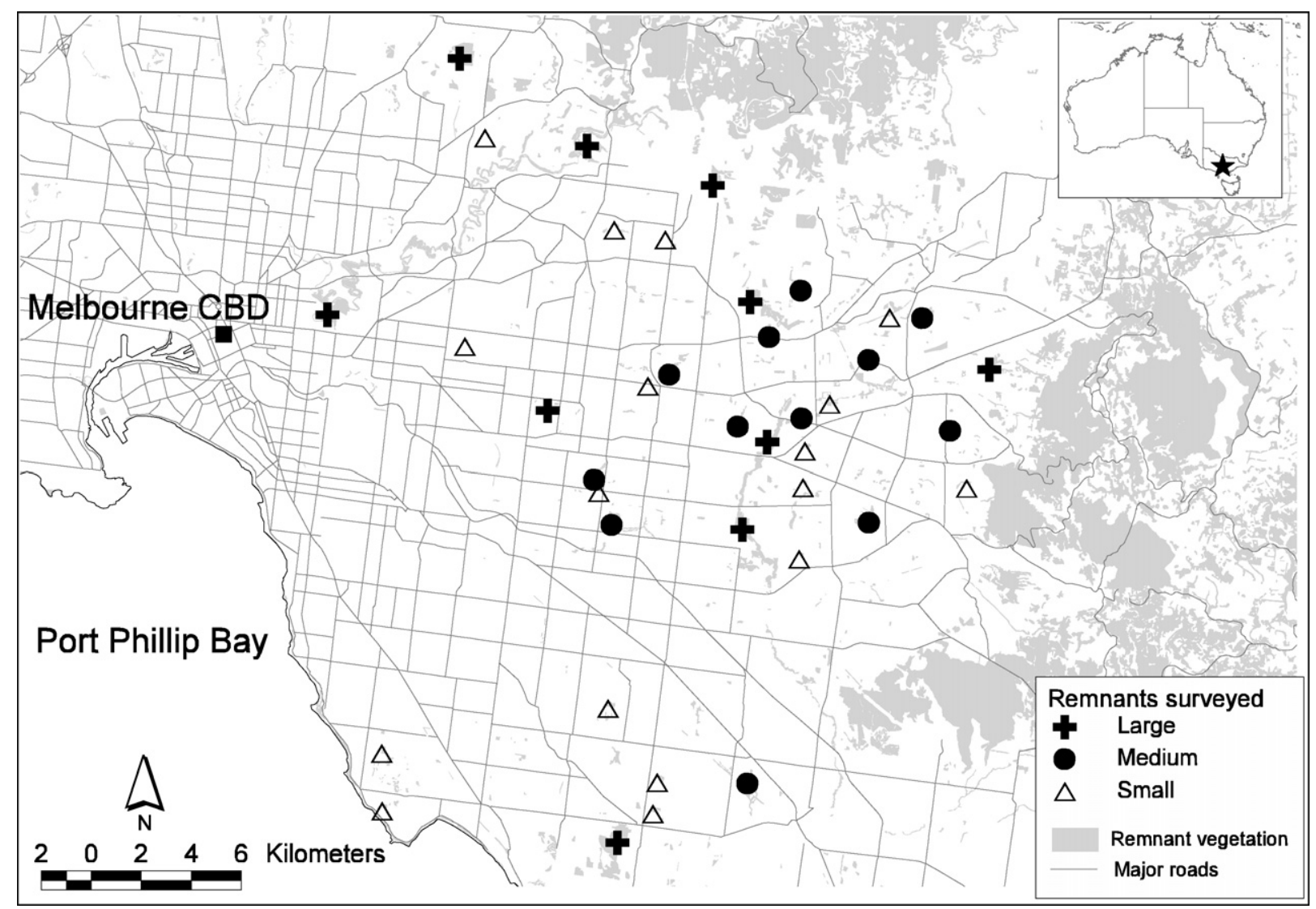

Fig. 1 - Locations of all study sites in the suburban zone of Melbourne, Australia.

account for greater habitat and structural heterogeneity which occurred in the larger reserves. Habitat and structural heterogeneity needs to be sampled adequately to provide an accurate assessment of bird species richness within a rem nant. Transects were located away from the edges of the rem nants where possible. Surveys were conducted during the non breeding season (April July) of 2003 and breeding season (October February) of 2003/04. Each transect was surveyed four times in each season, on different days, between dawn and midday during favourable conditions (days of high wind or rain were avoided). The multiple transects within medium and large remnants were surveyed on the same day. All sur veys were conducted by experienced bird observers (M.J.A., J.A.F., G.C.P.).

Each transect was traversed over a 10 min period and all birds seen and heard within the bounds of the transect were recorded, including those flying above the canopy. The results from all transects within a remnant were then pooled to pro vide an indication of the richness of each remnant. Nocturnal surveys were not undertaken and therefore species active at night (e.g. owls) were poorly sampled. Aquatic birds, intro duced birds and presumed aviculture escapees were excluded from consideration in this paper.

Species were classified into a series of ecological groups based on resilience to urbanization, foraging location and migratory status (Table 1). Species were also classified into landscape response groups based on findings from a previous study where bird communities were surveyed within the ur ban matrix (streetscapes) as well as within remnant vegeta tion (see White et al., 2005). Matrix tolerant species were defined as those species found in $>5$ of the 27 streetscape sites used in White et al. (2005). Remnant reliant species were those found in $\leqslant 5$ of the 27 streetscape sites used in White et al. (2005). Bird species were assigned to foraging groups based on a combination of previous assessments and pub lished information (e.g. Recher and Holmes, 1985; Ford et al., 1986; Mac Nally, 1994,1996; Loyn, 1998; Tzaros, 2001), and observations made by the authors and the opinion of ex perts. The species were also categorized into migrant groups (migrant, partial migrant or non migrant) based on the large scale movement patterns described by Griffioen and Clarke (2002) from analyses of the Atlas of Australian Birds database for southeastern Australia.

\subsection{Habitat measures}

Habitat assessments were conducted at each site. Four $20 \mathrm{~m} \times 20 \mathrm{~m}$ quadrats were established at $50 \mathrm{~m}$ intervals along each bird survey transect. The results across all quadrats within a particular remnant were averaged. Measures were taken of canopy cover and also different ground cover attri butes, including the number of logs and the \% cover of leaf lit ter, bare ground, native grasses and herbs within each quadrat. Measures were also taken of the \% cover of low shrubs up to $1.5 \mathrm{~m}$ and tall shrubs between $1.5 \mathrm{~m}$ and $3 \mathrm{~m}$ within each quadrat. A geographical information system 
Table 1 - Bird species recorded in urban remnant vegetation in Melbourne, and predominant foraging location, migratory status and tolerance of urban matrix

\begin{tabular}{|c|c|c|c|c|}
\hline Common name & Species name & Foraging location & Migrant status & Matrix tolerance ${ }^{*}$ \\
\hline Common bronzewing & Phaps chalcoptera & G & $\mathrm{N}$ & $\mathrm{n}$ \\
\hline Crested pigeon & Ocyphaps lophotes & G & $\mathrm{N}$ & $\mathrm{n}$ \\
\hline Tawny frogmouth & Podargus strigoides & G & $\mathrm{N}$ & $\mathrm{n}$ \\
\hline Whistling kite & Haliastur sphenurus & G & $\mathrm{N}$ & $\mathrm{n}$ \\
\hline Collared sparrowhawk & Accipiter cirrhocephalus & C & $\mathrm{N}$ & $\mathrm{n}$ \\
\hline Little eagle & Hieraaetus morphnoides & G & $\mathrm{N}$ & $\mathrm{n}$ \\
\hline Nankeen kestrel & Falco cenchroides & G & $\mathrm{N}$ & $\mathrm{n}$ \\
\hline Australian hobby & Falco longipennis & $\mathrm{C}$ & $\mathrm{N}$ & $\mathrm{n}$ \\
\hline Yellow tailed black cockatoo & Calyptorhynchus funereus & $\mathrm{C}$ & $\mathrm{P}$ & $\mathrm{n}$ \\
\hline Gang gang cockatoo & Callocephalon fimbriatum & $\mathrm{C}$ & M & $\mathrm{n}$ \\
\hline Galah & Eolophus roseicapillus & G & $\mathrm{N}$ & $\mathrm{n}$ \\
\hline Long billed corella & Cacatua tenuirostris & G & $\mathrm{N}$ & $\mathrm{n}$ \\
\hline Little corella & Cacatua sanguinea & G & $\mathrm{N}$ & $\mathrm{n}$ \\
\hline Sulphur crested cockatoo & Cacatua galerita & G & $\mathrm{N}$ & $\mathrm{n}$ \\
\hline Rainbow lorikeet & Trichoglossus haematodus & $\mathrm{C}$ & $\mathrm{N}$ & $\mathrm{y}$ \\
\hline Musk lorikeet & Glossopsitta concinna & C & $\mathrm{P}$ & $\mathrm{y}$ \\
\hline Little lorikeet & Glossopsitta pusilla & $\mathrm{C}$ & $\mathrm{P}$ & $\mathrm{n}$ \\
\hline Australian King parrot & Alisterus scapularis & C & $\mathrm{P}$ & $\mathrm{n}$ \\
\hline Crimson rosella & Platycercus elegans & $\mathrm{C}$ & $\mathrm{N}$ & $\mathrm{n}$ \\
\hline Eastern rosella & Platycercus eximius & G & $\mathrm{N}$ & $\mathrm{n}$ \\
\hline Swift parrot & Lathamus discolor & C & $\mathrm{M}$ & $\mathrm{n}$ \\
\hline Red rumped parrot & Psephotus haematonotus & G & $\mathrm{N}$ & $\mathrm{n}$ \\
\hline Shining bronze cuckoo & Chalcites lucidus & $\mathrm{S}$ & M & $\mathrm{n}$ \\
\hline Pallid cuckoo & Cacomantis pallidus & $\mathrm{S}$ & M & $\mathrm{n}$ \\
\hline Fan tailed cuckoo & Cacomantis flabelliformis & $\mathrm{S}$ & $\mathrm{M}$ & $\mathrm{n}$ \\
\hline Powerful owl & Ninox strenua & $\mathrm{C}$ & $\mathrm{N}$ & $\mathrm{n}$ \\
\hline Laughing kookaburra & Dacelo novaeguineae & G & $\mathrm{N}$ & $\mathrm{n}$ \\
\hline Sacred kingfisher & Todiramphus sanctus & G & M & $\mathrm{n}$ \\
\hline White throated treecreeper & Corombates leucophaea & C & $\mathrm{N}$ & $\mathrm{n}$ \\
\hline Superb fairy wren & Malurus cyaneus & G & $\mathrm{N}$ & $\mathrm{n}$ \\
\hline White browed scrubwren & Sericornis frontalis & G & $\mathrm{N}$ & $\mathrm{n}$ \\
\hline White throated gerygone & Gerygone albogularis & $\mathrm{C}$ & $\mathrm{M}$ & $\mathrm{n}$ \\
\hline Striated thornbill & Acanthiza lineata & $\mathrm{C}$ & $\mathrm{N}$ & $\mathrm{n}$ \\
\hline Yellow thornbill & Acanthiza nana & $\mathrm{C}$ & $\mathrm{N}$ & $\mathrm{n}$ \\
\hline Brown thornbill & Acanthiza pusilla & $\mathrm{S}$ & $\mathrm{N}$ & $\mathrm{y}$ \\
\hline Spotted pardalote & Pardalotus punctatus & $\mathrm{C}$ & $\mathrm{N}$ & $\mathrm{y}$ \\
\hline Striated pardalote & Pardalotus striatus & $\mathrm{C}$ & $\mathrm{P}$ & $\mathrm{n}$ \\
\hline Eastern spinebill & Acanthorhynchus tenuirostris & $\mathrm{S}$ & $\mathrm{P}$ & $\mathrm{y}$ \\
\hline Lewin's honeyeater & Meliphaga lewinii & $\mathrm{C}$ & $\mathrm{P}$ & $\mathrm{n}$ \\
\hline Yellow faced Honeyeater & Lichenostomus chrysops & $\mathrm{C}$ & $\mathrm{P}$ & $\mathrm{n}$ \\
\hline White eared honeyeater & Lichenostomus leucotis & $\mathrm{C}$ & $\mathrm{N}$ & $\mathrm{n}$ \\
\hline White plumed honeyeater & Lichenostomus penicillatus & $\mathrm{C}$ & $\mathrm{N}$ & $\mathrm{y}$ \\
\hline Bell miner & Manorina melanophrys & C & $\mathrm{N}$ & $\mathrm{n}$ \\
\hline Noisy miner & Manorina melanocephala & $\mathrm{C}$ & $\mathrm{N}$ & $\mathrm{y}$ \\
\hline Little wattlebird & Anthochaera chrysoptera & $\mathrm{S}$ & $\mathrm{N}$ & $\mathrm{y}$ \\
\hline Red wattlebird & Anthochaera carunculata & $\mathrm{C}$ & $\mathrm{P}$ & $\mathrm{y}$ \\
\hline New Holland honeyeater & Phylidonyris novaehollandiae & $\mathrm{S}$ & $\mathrm{N}$ & $\mathrm{n}$ \\
\hline Brown headed honeyeater & Melithreptus brevirostris & $\mathrm{C}$ & $\mathrm{N}$ & $\mathrm{n}$ \\
\hline White naped honeyeater & Melithreptus lunatus & $\mathrm{C}$ & $\mathrm{P}$ & $\mathrm{n}$ \\
\hline Varied sittella & Daphoenositta chrysoptera & $\mathrm{C}$ & $\mathrm{N}$ & $\mathrm{n}$ \\
\hline Black faced cuckoo shrike & Coracina novaehollandiae & $\mathrm{C}$ & $\mathrm{P}$ & $\mathrm{n}$ \\
\hline Crested shrike tit & Falcunculus frontatus & $\mathrm{C}$ & $\mathrm{N}$ & $\mathrm{n}$ \\
\hline Golden whistler & Pachycephala pectoralis & $\mathrm{S}$ & $\mathrm{P}$ & $\mathrm{n}$ \\
\hline Rufous whistler & Pachycephala rufiventris & $\mathrm{S}$ & M & $\mathrm{n}$ \\
\hline Grey shrike thrush & Colluricincla harmonica & $\mathrm{S}$ & $\mathrm{N}$ & $\mathrm{n}$ \\
\hline Olive backed oriole & Oriolus sagittatus & $\mathrm{C}$ & M & $\mathrm{n}$ \\
\hline Dusky woodswallow & Artamus cyanopterus & $\mathrm{C}$ & M & $\mathrm{n}$ \\
\hline Grey butcherbird & Cracticus torquatus & $\mathrm{S}$ & $\mathrm{N}$ & $\mathrm{y}$ \\
\hline Australian magpie & Cracticus tibicen & G & $\mathrm{N}$ & $\mathrm{y}$ \\
\hline Pied currawong & Strepera graculina & $\mathrm{C}$ & $\mathrm{P}$ & $\mathrm{n}$ \\
\hline Grey currawong & Strepera versicolor & $\mathrm{C}$ & $\mathrm{P}$ & $\mathrm{n}$ \\
\hline Rufous fantail & Rhipidura rufifrons & $\mathrm{S}$ & $\mathrm{M}$ & $\mathrm{n}$ \\
\hline
\end{tabular}


Table 1 - continued

\begin{tabular}{|c|c|c|c|c|}
\hline Common name & Species name & Foraging location & Migrant status & Matrix tolerance \\
\hline Grey fantail & Rhipidura albiscapa & $\mathrm{s}$ & $P$ & $\mathrm{n}$ \\
\hline Willie wagtail & Rhipidura leucophrys & G & $\mathrm{N}$ & $\mathrm{n}$ \\
\hline Australian raven & Corvus coronoides & G & $\mathrm{N}$ & $\mathrm{n}$ \\
\hline Little raven & Corvus mellori & G & $\mathrm{N}$ & $\mathrm{y}$ \\
\hline Satin flycatcher & Myiagra cyanoleuca & C & $\mathrm{M}$ & $\mathrm{n}$ \\
\hline Magpie lark & Grallina cyanoleuca & G & $\mathrm{N}$ & $\mathrm{y}$ \\
\hline Scarlet robin & Petroica boodang & G & $P$ & $\mathrm{n}$ \\
\hline Rose robin & Petroica rosea & S & $\mathrm{M}$ & $\mathrm{n}$ \\
\hline Eastern yellow robin & Eosaltrica australis & G & $\mathrm{N}$ & $\mathrm{n}$ \\
\hline Australian reed warbler & Acrocephalus australis & $\mathrm{s}$ & $\mathrm{M}$ & $\mathrm{n}$ \\
\hline Silvereye & Zosterops lateralis & $\mathrm{s}$ & $\mathrm{P}$ & $\mathrm{y}$ \\
\hline Welcome swallow & Hirundo neoxena & C & $\mathrm{N}$ & $\mathrm{n}$ \\
\hline Tree Martin & Petrochelidon nigricans & C & M & $\mathrm{n}$ \\
\hline Bassian thrush & Zoothera lunulata & G & $\mathrm{N}$ & $\mathrm{n}$ \\
\hline Mistletoebird & Dicaeum hirundinaceum & C & $P$ & $\mathrm{n}$ \\
\hline Red browed finch & Neochmia temporalis & G & $\mathrm{N}$ & $\mathrm{n}$ \\
\hline
\end{tabular}

(ArcView GIS 3.3) was used to determine the size of each rem nant patch, the proportion of the remnant that was made up of riparian vegetation and the proportion of remnant vegeta tion within a $1 \mathrm{~km}$ radius of the surveyed remnant.

To reduce the number of habitat variables used in the anal ysis we derived two habitat complexity scores (Table 2). The first complexity score was for canopy and shrub complexity, and was derived from the data for canopy cover, low shrub cover and tall shrub cover (Table 2). The second complexity score was based on ground layer resources and included the $\%$ cover of leaf litter and native ground cover, and the number of logs per quadrat (Table 2). Spearman rank correlations were conducted to examine the relationship between each of the variables used to characterize the sites.

\subsection{Statistical analysis}

A two factor analysis of variance (ANOVA) was used to deter mine if species richness had stabilized over the eight survey visits to each remnant and across the three broad remnant size categories. Tukeys post hoc tests were used to identify differences within the ANOVA at an alpha level of 0.05 .
To determine the relationships between the richness of native species within remnants and habitat variables, an information theoretic approach was taken, as described by Burnham and Anderson (2002). As this study had a relatively small sample size and the data were not overdispersed, the second order Akaike information criterion corrected for small sample sizes (AICc) was utilized. Generalized linear models using a Gaussian distribution were used to investigate the relationship between the total richness of species, matrix tol erant species, remnant reliant species, ground foraging spe cies, shrub foraging species, canopy foraging species, migrants, partial migrants and non migrants and a series of predictor habitat variables. The predictor variables applied in all analyses were the area (ha) of the remnant (Log10) (termed remnant area), the canopy/shrub complexity score, the ground complexity score, the proportion of a $1 \mathrm{~km}$ buffer around each remnant that consisted of remnant vegetation (termed \% buffer remnant vegetation) and the proportion of the remnant that was comprised of riparian vegetation (termed \% riparian vegetation).

Akaike differences ( $\triangle \mathrm{AIC}$ ) were used to determine the level of support for each model in the candidate set. Burnham and

Table 2 - Contributors to habitat complexity scores

Contribution to score

\begin{tabular}{|c|c|c|c|c|c|c|}
\hline & & \multicolumn{5}{|c|}{ Contribution to score } \\
\hline & & 0 & 1 & 2 & 3 & 4 \\
\hline \multirow[t]{3}{*}{ Contributors to canopy/shrub complexity score } & Canopy cover & $04.9 \%$ & $519.9 \%$ & $2034.9 \%$ & $3549.9 \%$ & $50+\%$ \\
\hline & Low shrub $(01.5 \mathrm{~m})$ cover & $04.9 \%$ & $514.9 \%$ & $1524.9 \%$ & $2534.9 \%$ & $35+\%$ \\
\hline & Tall shrub $(1.63 \mathrm{~m})$ cover & $04.9 \%$ & $59.9 \%$ & $1014.9 \%$ & $1519.9 \%$ & $20+\%$ \\
\hline \multirow[t]{3}{*}{ Contributors to ground complexity score } & Leaf litter cover & $014.9 \%$ & $1529.9 \%$ & $3044.9 \%$ & $4559.9 \%$ & $60+\%$ \\
\hline & Native ground cover & $04.9 \%$ & $519.9 \%$ & $2034.9 \%$ & $3549.9 \%$ & $50+\%$ \\
\hline & Number of logs & 02 & 37 & 811 & 1217 & $18+$ \\
\hline
\end{tabular}


Anderson (2002) suggest that candidate models with Akaike differences less than 2 have substantial support as being the best of the candidate set of models. Akaike weights $\left(\omega_{i}\right)$ were additionally used to determine the evidence of support for each model. Akaike weights are the proportional weight of evidence in support of the particular model being the best model for the situation (Burnham and Anderson, 2002). Summed AIC weights were also used to help identify influen tial predictor variables in the models. The AIC weights are summed for all models that include a particular variable, with a highly influential variable being able to have a maximum weight of 1 .

Model averaging was used to give un conditional model variances when the Akaike weight suggested no individual model was clearly the best $\left(\omega_{i}>0.9\right)$ (Anderson et al., 2001). Weighted model averaging based on 1000 bootstrapped sam ples was used to reduce model selection bias. Hierarchical partitioning was used to determine the independent contri bution of each predictor variable to the overall model. Models were developed using $R$ statistical packages (Ihaka and Gen tleman, 1996), using algorithms to calculate AICc, bootstrap frequencies, and model averaged estimates (Scroggie, unpub lished). Hierarchical partitioning was undertaken in $R$ using the hier.part package (Walsh and Mac Nally, 2003).

\section{Results}

The site based habitat and landscape variables differed con siderably across the 39 remnants. Remnant area ranged from 1 ha to 107 ha with a mean of 16.13 ha ( \pm 3.68 ha $1 \mathrm{SE}$ ). Canopy/ shrub complexity scores ranged from 1 to 10 out of a possible 12 , with a mean of $4.67( \pm 0.341 \mathrm{SE})$. Ground complexity scores ranged from 1 to 10 out of a possible 12, with a mean of 5.85 $( \pm 0.321 \mathrm{SE})$. The \% buffer remnant vegetation ranged from $0 \%$ to $12 \%$, with a mean of $2.99 \%( \pm 0.461 \mathrm{SE})$. The \% riparian veg etation ranged from $0 \%$ to $100 \%$ with a mean of $14.78 \%$ $( \pm 4.00 \% 1 \mathrm{SE})$. A series of Spearman rank correlations exam ined potential relationships between the site based variables. Even though we reduced the number of potential variables there were some relationships between the variables suggest ing some degree of co linearity. The \% riparian vegetation was positively related to the size of the remnant $\left(r_{\mathrm{s}}\right.$ 0.550, $P<0.001)$. The ground complexity score was positively corre lated with the canopy/shrub complexity score $\left(r_{\mathrm{s}} \quad 0.518\right.$, $P$ 0.001). The \% buffer remnant vegetation was positively correlated with the size of the remnant $\left(r_{\mathrm{s}} \quad 0.384, \mathrm{P}<0.016\right)$. The $\%$ buffer remnant vegetation was positively correlated with the $\%$ riparian vegetation $\left(r_{\mathrm{s}} \quad 0.338, P<0.035\right)$. The ground complexity score was positively correlated with rem nant area $\left(r_{\mathrm{s}} \quad 0.323, \mathrm{P}<0.045\right)$.

Seventy nine native bird species were recorded during this study (see Table 1 for common and species names). A further six introduced species were also recorded. The response of introduced species to remnant characteristics has been re ported elsewhere (Antos et al., 2006), and they are not consid ered here. Species richness was effected by the size class of the remnant $\left(F_{(2,288)} \quad 12.886, P<0.001\right)$ with each increase in size class leading to an increase in species richness (Tukey $P<0.05$ ). Species richness was also effected by the visit num ber $\left(F_{(7,288)} 239.488, P<0.001\right)$. Species richness increased with each visit until the sixth visit (Tukey $P<0.05$ ). There was no significant increase in richness detected between the sixth and eighth visits (Tukey $P>0.05$ ) suggesting the sampling intensity was sufficient to lead to stabilized esti mates of species richness. There was no interaction between the size class of the remnants and the visit number $\left(F_{(14,288)} \quad 0.990, P \quad 0.464\right)$, suggesting that species accumula tion followed a similar pattern in different size class remnants.

\subsection{Total species richness}

A total of seven models were produced with delta AIC values $<2$, suggesting some evidence for multiple explanatory mod els (Table 3). The candidate sub set of models also had high $R^{2}$ values ranging from 0.664 to 0.695 , and as such explained a large amount of the variation in the data. Weight ratios sug gest strong support for the first two models, but low Akaike weights for the main models suggest some model uncer tainty. Hierarchical partitioning and model averaging was conducted as no individual model was supported. Model aver aging showed strong support for a positive relationship be tween species richness and remnant area, with hierarchical partitioning also suggesting a strong independent contribu tion from remnant area (Table 4). Summed AIC weights also showed strong support for remnant area being included in any model (Table 4). The \% riparian vegetation also had high independent contributions and summed AIC weights sug gesting some support for models including \% riparian vegeta tion (Table 4). Overall, the total richness of species appears to be largely associated with remnant area and to a lesser extent the $\%$ riparian vegetation in the remnant.

\subsection{Matrix-tolerant and remnant-reliant species}

A total of 14 species were regarded as tolerant of the urban matrix (Table 1). The remaining 65 species were regarded as remnant reliant species. The richness of matrix tolerant spe cies was modeled against each of the predictor variables. There were five models with delta AIC values $<2$. However, very low $R^{2}$ values suggest that the models have limited explanatory power (Table 3). Model averaging suggested that remnant area may have a positive effect on the number of matrix tolerant species found in patches, but due to the ex tremely low $R^{2}$ values we consider this a weak response.

The richness of remnant reliant species was also modeled against each of the predictor variables. Five models were developed with substantial support to explain the richness of these species (Table 3 ). High $R^{2}$ values suggest strong explanatory power of each of the supported models. It was necessary to conduct model averaging as no one model had substantial support on its own. Model averaging suggests that the main contribution to the richness of remnant reliant spe cies was a positive relationship with remnant area (Table 4). Hierarchical partitioning indicated the remnant area had an independent contribution of $47.4 \%$, adding further support to the importance of this factor. Further to remnant area, the \% riparian vegetation had an independent contribution of $10.8 \%$ and moderate summed AIC weights. 
Table 3 - AIC $_{\mathrm{C}}$ based model selection for different ecological groups of species

\begin{tabular}{|c|c|c|c|c|c|c|c|c|c|}
\hline & Model $^{*}$ & K & AICc & $\Delta \mathrm{AIC}$ & Ranks & $\omega_{\mathrm{i}}$ & $i$ & $R^{2}$ & $\omega_{i} / \omega_{j}$ \\
\hline \multirow[t]{7}{*}{ Total species richness } & Remnant area $+\%$ riparian vegetation & 4 & 237.6 & 0.000 & 1 & 0.185 & 0.214 & 0.686 & \\
\hline & Remnant area & 3 & 237.7 & 0.056 & 2 & 0.180 & 0.186 & 0.664 & 1.03 \\
\hline & $\begin{array}{l}\text { Remnant area + canopy/shrub } \\
\text { complexity }\end{array}$ & 4 & 239.0 & 1.431 & 3 & 0.090 & 0.106 & 0.674 & 2.06 \\
\hline & $\begin{array}{l}\text { Remnant area + canopy/shrub } \\
\text { complexity + \% riparian vegetation }\end{array}$ & 5 & 239.1 & 1.494 & 4 & 0.088 & 0.114 & 0.695 & 2.10 \\
\hline & $\begin{array}{l}\text { Remnant area }+\% \text { buffer remnant } \\
\text { vegetation }\end{array}$ & 4 & 239.2 & 1.555 & 5 & 0.085 & 0.086 & 0.673 & 2.18 \\
\hline & $\begin{array}{l}\text { Remnant area }+\% \text { buffer remnant } \\
\text { vegetation }+\% \text { riparian vegetation }\end{array}$ & 5 & 239.4 & 1.797 & 6 & 0.075 & 0.044 & 0.692 & 2.47 \\
\hline & $\begin{array}{l}\text { Remnant area + ground complexity }+\% \\
\text { riparian vegetation }\end{array}$ & 5 & 239.6 & 1.975 & 7 & 0.069 & 0.084 & 0.691 & 2.68 \\
\hline \multirow[t]{5}{*}{ Matrix tolerant species } & Remnant area & 3 & 166.0 & 0.000 & 1 & 0.191 & 0.206 & 0.179 & \\
\hline & $\begin{array}{l}\text { Remnant area + canopy/shrub } \\
\text { complexity + ground complexity }\end{array}$ & 5 & 167.0 & 0.758 & 2 & 0.131 & 0.242 & 0.266 & 1.46 \\
\hline & $\begin{array}{l}\text { Remnant area + canopy/shrub } \\
\text { complexity }\end{array}$ & 4 & 167.0 & 1.285 & 3 & 0.101 & 0.144 & 0.204 & 1.89 \\
\hline & Remnant area + ground complexity & 4 & 167.0 & 1.598 & 4 & 0.086 & 0.098 & 0.198 & 2.22 \\
\hline & Remnant area $+\%$ riparian vegetation & 4 & 168.0 & 1.858 & 5 & 0.076 & 0.030 & 0.193 & 2.51 \\
\hline \multirow{5}{*}{ Remnant reliant species } & Remnant area & 3 & 225.6 & 0.000 & 1 & 0.207 & 0.248 & 0.673 & \\
\hline & Remnant area $+\%$ riparian vegetation & 4 & 226.0 & 0.465 & 2 & 0.164 & 0.128 & 0.690 & 1.26 \\
\hline & $\begin{array}{l}\text { Remnant area }+\% \text { buffer remnant } \\
\text { vegetation }+\% \text { riparian vegetation }\end{array}$ & 5 & 227.1 & 1.493 & 3 & 0.098 & 0.162 & 0.702 & 2.11 \\
\hline & $\begin{array}{l}\text { Remnant area }+\% \text { buffer remnant } \\
\text { vegetation }\end{array}$ & 4 & 227.3 & 1.713 & 4 & 0.088 & 0.098 & 0.680 & 2.35 \\
\hline & Remnant area + ground complexity & 4 & 227.4 & 1.772 & 5 & 0.085 & 0.040 & 0.679 & 2.44 \\
\hline \multirow[t]{5}{*}{ Ground foraging species } & Remnant area & 3 & 177.0 & 0.000 & 1 & 0.219 & 0.208 & 0.573 & \\
\hline & $\begin{array}{l}\text { Remnant area + canopy/shrub } \\
\text { complexity }\end{array}$ & 4 & 178.0 & 0.327 & 2 & 0.186 & 0.230 & 0.596 & 1.18 \\
\hline & Remnant area + ground complexity & 4 & 179.0 & 1.776 & 3 & 0.090 & 0.036 & 0.581 & 2.43 \\
\hline & $\begin{array}{l}\text { Remnant area }+\% \text { buffer remnant } \\
\text { vegetation }\end{array}$ & 4 & 179.0 & 1.987 & 4 & 0.081 & 0.070 & 0.579 & 2.70 \\
\hline & $\begin{array}{l}\text { Remnant area + canopy/shrub } \\
\text { complexity + \% buffer remnant } \\
\text { vegetation }\end{array}$ & 5 & 179.0 & 2.011 & 5 & 0.080 & 0.102 & 0.606 & 2.74 \\
\hline \multirow[t]{5}{*}{ Shrub foraging species } & $\begin{array}{l}\text { Remnant area + canopy/shrub } \\
\text { complexity }\end{array}$ & 4 & 163.0 & 0.000 & 1 & 0.306 & 0.250 & 0.519 & \\
\hline & $\begin{array}{l}\text { Remnant area + canopy/shrub } \\
\text { complexity + \% riparian vegetation }\end{array}$ & 5 & 164.0 & 1.140 & 2 & 0.173 & 0.114 & 0.537 & 1.77 \\
\hline & $\begin{array}{l}\text { Remnant area + canopy/shrub } \\
\text { complexity + \% buffer remnant } \\
\text { vegetation }\end{array}$ & 5 & 164.0 & 1.640 & 3 & 0.135 & 0.104 & 0.531 & 2.27 \\
\hline & $\begin{array}{l}\text { Remnant area + canopy/shrub } \\
\text { complexity + ground complexity }\end{array}$ & 5 & 165.0 & 1.980 & 4 & 0.114 & 0.090 & 0.527 & 2.68 \\
\hline & $\begin{array}{l}\text { Remnant area + canopy/shrub } \\
\text { complexity + ground complexity }+\% \\
\text { riparian vegetation }\end{array}$ & 6 & 165.0 & 2.380 & 5 & 0.093 & 0.074 & 0.555 & 3.29 \\
\hline \multirow[t]{5}{*}{ Canopy foraging species } & Remnant area + \% riparian vegetation & 4 & 186.0 & 0.000 & 1 & 0.243 & 0.260 & 0.583 & \\
\hline & Remnant area & 3 & 186.0 & 0.173 & 2 & 0.223 & 0.246 & 0.554 & 1.09 \\
\hline & Remnant area + ground complexity & 4 & 188.0 & 2.431 & 3 & 0.072 & 0.090 & 0.556 & 3.38 \\
\hline & $\begin{array}{l}\text { Remnant area + canopy/shrub } \\
\text { complexity + \% riparian vegetation }\end{array}$ & 5 & 188.0 & 2.476 & 4 & 0.071 & 0.076 & 0.585 & 3.42 \\
\hline & $\begin{array}{l}\text { Remnant area + canopy/shrub } \\
\text { complexity }\end{array}$ & 4 & 188.0 & 2.493 & 5 & 0.070 & 0.078 & 0.556 & 3.47 \\
\hline \multirow[t]{3}{*}{ Migrants } & Remnant area & 3 & 126.0 & 0.000 & 1 & 0.203 & 0.120 & 0.305 & \\
\hline & $\begin{array}{l}\text { Remnant area }+\% \text { buffer remnant } \\
\text { vegetation }\end{array}$ & 4 & 126.0 & 0.131 & 2 & 0.190 & 0.208 & 0.346 & 1.07 \\
\hline & $\begin{array}{l}\text { Remnant area + canopy/shrub } \\
\text { complexity + \% buffer remnant } \\
\text { vegetation }\end{array}$ & 5 & 128.0 & 1.671 & 3 & 0.088 & 0.084 & 0.364 & 2.31 \\
\hline
\end{tabular}


Table 3 - continued

\begin{tabular}{|c|c|c|c|c|c|c|c|c|c|}
\hline & Model* & K & AICc & $\triangle \mathrm{AIC}$ & Ranks & $\omega_{i}$ & $i$ & $R^{2}$ & $\omega_{i} / \omega_{j}$ \\
\hline & Remnant area + \% riparian vegetation & 4 & 128.0 & 1.889 & 4 & 0.079 & 0.044 & 0.316 & 2.57 \\
\hline & $\begin{array}{l}\text { Remnant area + canopy/shrub } \\
\text { complexity }\end{array}$ & 4 & 128.0 & 1.905 & 5 & 0.078 & 0.136 & 0.316 & 2.60 \\
\hline & $\begin{array}{l}\text { Remnant area + \% riparian } \\
\text { vegetation }+\% \text { buffer remnant } \\
\text { vegetation }\end{array}$ & 5 & 128.0 & 1.945 & 6 & 0.077 & 0.106 & 0.360 & 2.64 \\
\hline \multirow[t]{5}{*}{ Partial migrants } & $\begin{array}{l}\text { Remnant area + canopy/shrub } \\
\text { complexity }\end{array}$ & 4 & 174.0 & 0.000 & 1 & 0.315 & 0.406 & 0.501 & \\
\hline & Remnant area & 3 & 176.0 & 1.650 & 2 & 0.138 & 0.204 & 0.445 & 2.28 \\
\hline & $\begin{array}{l}\text { Remnant area + canopy/shrub } \\
\text { complexity + \% riparian vegetation }\end{array}$ & 5 & 176.0 & 2.470 & 3 & 0.092 & 0.038 & 0.503 & 3.42 \\
\hline & $\begin{array}{l}\text { Remnant area + canopy/shrub } \\
\text { complexity + \% buffer remnant } \\
\text { vegetation }\end{array}$ & 5 & 176.0 & 2.590 & 4 & 0.086 & 0.024 & 0.502 & 3.66 \\
\hline & $\begin{array}{l}\text { Remnant area + canopy/shrub } \\
\text { complexity + ground complexity }\end{array}$ & 5 & 176.0 & 2.640 & 5 & 0.084 & 0.080 & 0.501 & 3.75 \\
\hline \multirow[t]{5}{*}{ Non migrants } & Remnant area + \% riparian vegetation & 4 & 211.0 & 0.000 & 1 & 0.347 & 0.370 & 0.626 & \\
\hline & Remnant area & 3 & 213.0 & 2.120 & 2 & 0.120 & 0.172 & 0.579 & 2.89 \\
\hline & $\begin{array}{l}\text { Remnant area + ground complexity + \% } \\
\text { riparian vegetation }\end{array}$ & 5 & 213.0 & 2.480 & 3 & 0.101 & 0.096 & 0.627 & 3.44 \\
\hline & $\begin{array}{l}\text { Remnant area }+\% \text { buffer remnant } \\
\text { vegetation }+\% \text { riparian vegetation }\end{array}$ & 5 & 213.0 & 2.480 & 4 & 0.100 & 0.062 & 0.627 & 3.47 \\
\hline & $\begin{array}{l}\text { Remnant area + canopy/shrub } \\
\text { complexity + \% riparian vegetation }\end{array}$ & 5 & 213.0 & 2.480 & 5 & 0.100 & 0.124 & 0.627 & 3.47 \\
\hline
\end{tabular}

Models based on the number of species present within each group at each site. Values represent the number of parameters (K), Akaike information criterion corrected for small sample sizes $\left(\mathrm{AIC}_{\mathrm{C}}\right)$, AIC differences $(\triangle \mathrm{AIC})$, Akaike weights $\left(\omega_{\mathrm{i}}\right)$, bootstrap selection frequencies (i) and regression explanation scores $\left(R^{2}\right)$ for the best models and evidence ratios $\left(\omega_{\mathrm{i}} / \omega_{\mathrm{j}}\right)$. The highest five models are provided. Extra models are provided if more than five models had a $\triangle$ AIC score of less than 2.

* Model variables include : remnant area = area of woodland patch in hectares (logged), canopy/shrub complexity score, ground complexity score, the percent of a $1 \mathrm{~km}$ buffer around each remnant patch that is made up of other remnant vegetation (\% buffer remnant vegetation) and the percent of each remnant that is made up of riparian vegetation (\% riparian vegetation).

\subsection{Foraging location}

Species were divided into categories based on their domi nant foraging strata and substrates. Three broad foraging locations were identified, these being canopy, shrub layer and ground. Overall, 38 of the species recorded generally for age in the canopy, 16 in the shrub layer, and 25 on the ground (Table 1).

Models were developed examining the relationship be tween richness of ground foraging species and the five pre dictor variables. Four models were produced which had sub stantial support (Table 3). All the supported models included remnant area indicating the important role of remnant size. $R^{2}$ values suggest the models have the ability to explain rea sonable amounts of variation. Model averaging suggests that a relationship between remnant area and canopy/shrub com plexity may be important in determining the richness of ground foraging birds. High summed AIC values and high independent hierarchical partitioning contributions suggest that remnant area has a strong positive influence on the richness of ground foraging birds. Moderate summed AIC values also suggest that there is a negative relationship be tween canopy/shrub complexity and ground foraging species richness. Whilst canopy/shrub complexity has some impor tance it also has low independent contributions to the best model (Table 4). Hierarchical partitioning also suggests that the $\%$ riparian vegetation may have some influence, but the summed AIC weights do not support this. This indicates some degree of model uncertainty, but remnant area has a strong influential effect on the richness of ground foraging birds.

A total of four models had substantial support in explain ing the richness of shrub foraging species (Table 3). All four supported models included remnant area and canopy/shrub complexity, suggesting these measures are important. The models derived had moderate $R^{2}$ values suggesting reason able explanatory power. As no model had strong support as the best, a model averaging approach was taken. Model aver aged coefficients suggest a positive relationship between the richness of shrub foraging species and remnant area and can opy/shrub complexity (Table 4). High summed AIC values and independent hierarchical partitioning contributions suggest that both these variables have a positive influence on the richness of shrub foraging birds.

Two models had substantial support in explaining the richness of canopy foraging species (Table 3). These two mod els indicated that either remnant area or remnant area in combination with the \% riparian vegetation could explain the pattern observed. Moderate $R^{2}$ values suggest that the models have reasonable explanatory power. Model averaging still highlighted that the two previous models are the best to explain the patterns (Table 3). High summed AIC weights and an independent contribution of $49.6 \%$ in the hierarchical 
Table 4 - Model averaged coefficients, conditional and un-conditional standard errors, Z-scores and significance of each variable in each species richness model, and summed AIC weights (total AIC weight for each model including that variable)

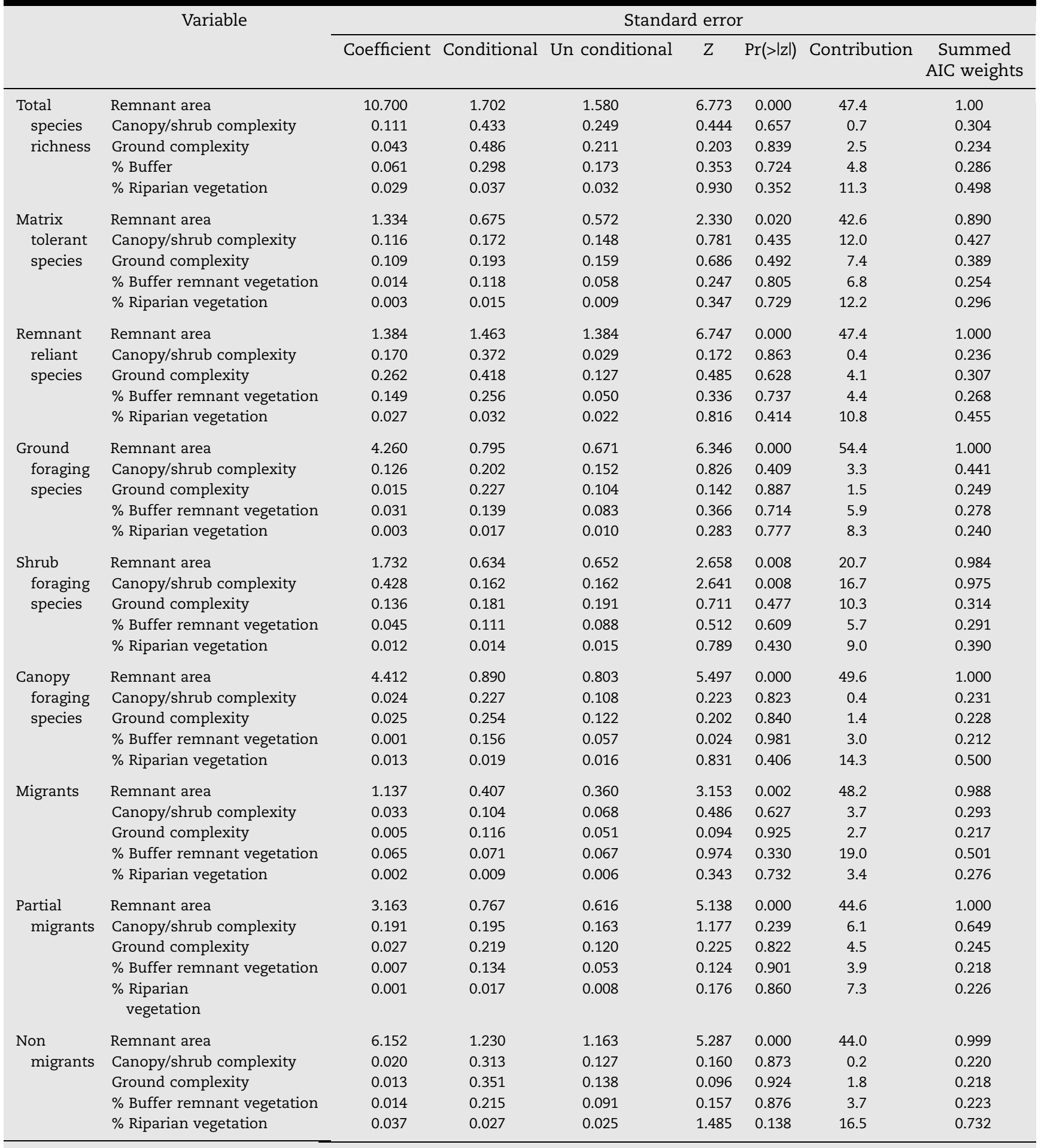

Results from hierarchical partitioning are shown, with the percentage independent contribution. See Table 3 for definition of model variables.

partitioning suggest that remnant area has a strong positive influence on canopy foraging species richness (Table 4). Lower independent contributions from the \% riparian vegetation and reduced summed AIC weights suggest that this variable has less influence than remnant area on richness of canopy foraging species (Table 4).

\subsection{Migrant status}

Species were categorized based on their migratory status into the following groups migrant (15 species), partial migrant (18 species) or resident (46 species) (Table 1). A total of six models were produced which had support for explaining 
patterns in the richness of migrant species (Table 3). Whilst the models have limited explanatory ability $\left(R^{2}\right.$ ranged from 0.305 and 0.364 ) the models all included remnant area along with other variables. As no one model was strongly supported as the best, model averaging was conducted. Model averaging suggested that the top model could include remnant area and $\%$ buffer remnant vegetation. A $48.2 \%$ independent contribu tion and a summed AIC weight of 0.988 (Table 4) suggests that remnant area is highly influential on the richness of migrant species. Further to this, an independent contribution of $19 \%$ and a moderate summed AIC weight suggests that $\%$ buffer remnant vegetation does have a moderate positive influence on the richness of migratory species (Table 4).

When examining the richness of partial migrants two pos sible explanatory models were produced from AIC. The top model included remnant area and canopy/shrub complexity (Table 3). Whilst this model had reasonable support (AIC weight 0.315 ) it was necessary to conduct model averaging. After model averaging the same model was the top model with a boot weight of 0.406 (Table 3). Remnant area was the strongest influencing factor (positive relationship) with an independent contribution of $44.6 \%$ and summed AIC weights of 1.000 (Table 4). The complexity of the canopy/shrub layer also had a positive influence on species richness, but to a les ser extent, with an independent contribution of $6.1 \%$ and summed AIC weights of 0.649 (Table 4).

Only one model was produced to explain the richness of non migrant species (Table 3). This model included remnant area and \% riparian vegetation, but it had low AIC weights (Table 3), suggesting it may not be a good model to explain the patterns. Model averaging again supported this model as the most likely explanation of patterns in non migrant spe cies richness (Table 3). Overall, there was a positive effect of remnant area and to a lesser extent \% riparian vegetation. Remnant area had a 44.6\% independent contribution and high summed AIC weights (Table 4$)$. The $\%$ riparian vegetation had an independent contribution of $16.5 \%$ and high summed AIC weights (Table 4).

\section{Discussion}

The influence of remnant size on the occurrence and richness of various taxa has been well documented (e.g. Ambuel and
Temple, 1983; Freemark and Merriam, 1986; Bennett and Ford, 1997; Abensperg Traun et al., 2000). Most studies have fo cused on agricultural systems, often where the surrounding matrix contrasts starkly with the remnant (e.g. cropland) (although see Park and Lee, 2000; Fernández Juricic and Jok imäki, 2001; Mörtberg, 2001; Smith, 2007, for examples from the Northern Hemisphere). Our study has demonstrated that remnant size is a key determinant of avian species richness in remnant vegetation (except for matrix tolerant species) with in an urban context and a variegated landscape. While it has been previously determined that the structure and composi tion of bird assemblages differs between remnants of indige nous vegetation and the urban matrix (e.g. Parsons et al., 2003; White et al., 2005), our research also indicates that both landscape and structural characteristics can contribute to determining the species richness of individual remnants, but to a lesser extent than remnant size. Various aspects of the matrix may influence bird composition in woodland rem nants by providing resources which enable persistence or movement between remnants or conversely, barriers or threats (e.g. Jokimäki and Huhta, 2000; Dunford and Free mark, 2004; White et al., 2005; Pidgeon et al., 2007).

All of the ecological groups of native bird species that we examined, except matrix tolerant species (i.e. generalist spe cies), showed a strong and consistent positive association with remnant area (Table 5). The benefits of larger remnants to birds within the urban matrix are likely to be similar to those that have been proposed for agricultural systems. First, by sheer virtue of their size, larger remnants are more likely to support sustainable populations of species with more demanding resource requirements (e.g. top order predators). Second, larger remnants are more likely to contain greater habitat and environmental heterogeneity and thus provide suitable habitats for a wider array of species. Finally, larger patches support larger core areas which are less susceptible to edge effects such as increased temperature fluxes, weed invasion and the presence of predatory or parasitic species (Saunders et al., 1991; Antos and White, 2004).

As well as remnant size, another variable which made a positive contribution to explanatory models for most ecolog ical groups of native bird species was the increasing propor tion of riparian habitat (Table 5). Riparian zones provide high quality habitat for wildlife in the landscape (Catterall, 1993;

Table 5 - Relative strength of relationship between avian ecological groups and habitat variables based on an assessment of AIC outcomes and hierarchical partitioning

\begin{tabular}{|c|c|c|c|c|c|}
\hline & Remnant area & $\begin{array}{c}\text { Canopy/shrub } \\
\text { complexity }\end{array}$ & $\begin{array}{l}\text { Ground } \\
\text { complexity }\end{array}$ & $\begin{array}{c}\% \text { Buffer remnant } \\
\text { vegetation }\end{array}$ & \% Riparian vegetation \\
\hline Total species & Strong positive & & & & Moderate positive \\
\hline Matrix tolerant species & Weak positive & & & & \\
\hline Remnant reliant species & Strong positive & & & & Weak positive \\
\hline Ground foraging species & Strong positive & Weak negative & & & \\
\hline Shrub foraging species & Moderate positive & Moderate positive & & & \\
\hline Canopy foraging species & Strong positive & & & & Moderate positive \\
\hline Migrant & Strong positive & & & Moderate positive & \\
\hline Partial migrants & Strong positive & Moderate positive & & & \\
\hline Non migrants & Strong positive & & & & Moderate positive \\
\hline
\end{tabular}


Palmer and Bennett, 2006). They are often characterized by increased productivity and greater structural complexity of vegetation when compared to surrounding non riparian areas in the landscape (Tzaros, 2001; Palmer and Bennett, 2006). In addition, riparian zones in urban landscapes com monly retain native vegetation in a linear corridor and potentially provide high vegetative connectivity and con duits for movement through the landscape. Riparian zones are mostly excluded from infrastructure development, espe cially on floodplains, and are often retained as corridors of open space in the urban matrix that often support native vegetation (Jim and Chen, 2003; Livingston et al., 2003; Find lay and Taylor, 2006).

Remnant reliant birds were strongly linked to large patches of remnant vegetation in the urban landscape. These birds are characteristic of forest and woodlands in southeastern Aus tralia (Loyn, 1985; Emison et al., 1987), but do not occur widely in the urban matrix outside of native vegetation patches (White et al., 2005). Small remnants ( $<2$ ha) may be entirely composed of edge habitat (Forman et al., 1976) and therefore are likely to provide low value habitat for remnant reliant birds. This study has demonstrated that bird assemblages in small remnants are largely comprised of matrix tolerant spe cies which move freely between remnants and the urban ma trix and therefore are not sensitive to remnant size. The dependence of remnant reliant birds on relatively large areas of remnant vegetation makes them particularly vulnerable to extirpation from the urban environment as large areas of the urban matrix do not provide suitable habitat (White et al., 2005). Remnant reliant birds make a significant contribution to the richness of urban bird assemblages and therefore their conservation is important in maintaining urban biodiversity. Many remnant reliant species also contribute to remnant health by facilitating ecosystem processes such as pollination, insect control and the dispersal of certain plant species (e.g. Ford and Paton, 1986).

Group specific variations were evident and patch level characteristics were important for some ecological groups. For example, out of all foraging guilds, shrub foraging birds were least influenced by patch size alone and more influ enced by site characteristics (e.g. remnant area + canopy/ shrub complexity). This may indicate that vegetation struc ture (shrub density) is the key determinant of the presence of these species rather than remnant size. Generally, vegeta tion structure plays an important role in determining avian community structure in forested habitats (e.g. Willson, 1974; Gilmore, 1985).

Some long distance migrants, especially Neo tropical spe cies, can be more sensitive to remnant size than residents or partial (i.e. short distance) migrants (e.g. Ambuel and Temple, 1983). Many migratory species tend to decrease with increas ing urbanization (Beissinger and Osborne, 1982; Pennington et al., 2008). Our study found that migrants were positively influenced by the amount of other native vegetation within $1 \mathrm{~km}$ of the surveyed remnant, as well as by remnant size. The presence of nearby remnant vegetation may be impor tant by providing additional habitat and resources in the immediate vicinity that relatively mobile species are able to exploit. Surrounding native vegetation may also provide a more conspicuous visual cue for passing migratory species.
Urban areas can also provide greater access to some key re sources for migratory or nomadic species, such as nectar from non indigenous flower sources (e.g. Fitzsimons et al., 2003; Smith and Lill, 2008), than would be available in natural areas.

\subsection{Implications for conservation}

Conservation and restoration of native vegetation in the ur ban environment is becoming more prevalent. There is a growing recognition that areas of high conservation value can be found within the urban matrix (Catterall et al., 1991; Park and Lee, 2000; Savard et al., 2000; Fernández Juricic and Jokimäki, 2001).

The research presented in this paper provides conserva tion managers and planners with a hierarchical process to re serve design and management in order to conserve the highest richness of remnant reliant native species within ur ban areas.

First, conservation efforts should preferentially focus on the retention of larger remnants of native vegetation, given that remnant area had such an overriding influence on spe cies richness. A focus should also be placed on increasing the size of existing remnant vegetation where possible. This may include strategic revegetation to increase existing rem nant size and/or connectivity with nearby remnants where practical. While this may be a difficult task in many older cit ies where space is limited (e.g. Fernández Juricic and Jok imäki, 2001), it can be a valid approach within newer cities, such as those in Australia, or within recently developed peri urban areas.

Second, where possible, riparian vegetation should be in cluded within reserves or, where it is already present, should be protected from further degradation and managed for con servation purposes to ensure its integrity. Riparian zones are an effective location to focus revegetation, restoration and conservation efforts in urban landscapes. Due to develop ment restrictions along waterways (e.g. flood zones etc.) and their attractiveness for recreational activities, networks of riparian zones are often retained in urban landscapes and, if managed appropriately, are likely to have a critical role in forming habitat networks for wildlife.

Third, efforts should be focused at maintaining levels of vegetation structure and complexity that will cater for a wide range of different bird species (e.g. shrub complexity for shrub foraging species) although our results indicate that focusing efforts on improving vegetation structure may not be an optimal allocation of resources if the remnant is small and isolated. Resources may be better spent in increasing the size and connectivity of remnants within the urban matrix.

\section{Acknowledgements}

We thank the Parks Victoria Research Partners Panel for gen erously funding this research project. Thanks also to Chris Tzaros, Andrew Silcocks, Andrew Dunn and Dean Ingwersen for advice on foraging guilds and to Amber Cameron and Christina Wilson for collection of habitat data. Jukka Jokimäki and two anonymous referees provided comments which im proved the manuscript. 
Abensperg Traun, M., Smith, G.T., Main, B.Y., 2000. Terrestrial arthropods in a fragmented landscape: a review of ecological research in the western Australian central wheatbelt. Pacific Conservation Biology 6, 102119.

ABS, 2006. National Regional Profile: Melbourne (Statistical Division). Australian Bureau of Statistics, Canberra.

Ambuel, B., Temple, S.A., 1983. Area dependent changes in the bird communities and vegetation in southern Wisconsin forest. Ecology 64, 10571068

Anderson, D.R., Link, W.A., Johnson, D.H., Burnham, K.P., 2001. Suggestions for presenting the results of data analysis. Journal of Wildlife Management 65, 373378.

Antos, M.J., Fitzsimons, J.A., Palmer, G.C., White, J.G., 2006. Introduced birds in urban remnant vegetation: does remnant size really matter? Austral Ecology 31, 254261.

Antos, M.J., White, J.G., 2004. Birds of remnant vegetation on the Mornington Peninsula, Victoria, Australia: the role of interiors, edges and roadsides. Pacific Conservation Biology 9, 294301.

Beissinger, S.R., Osborne, D.R., 1982. Effects of urbanization on avian community organization. Condor $84,7583$.

Bennett, A.F., Ford, L.A., 1997. Land use, habitat change and the conservation of birds in fragmented rural environments: a landscape perspective from the Northern Plains, Victoria, Australia. Pacific Conservation Biology 3, 244261.

Bryant, M.M., 2006. Urban landscape conservation and the role of ecological greenways at local and metropolitan scales. Landscape and Urban Planning 76, 2344.

Burnham, K.P., Anderson, D.R., 2002. Model Selection and Multi model Inference: A Practical Information Theoretic Approach, second ed. Springer Verlag, New York, USA.

Buxton, M., Tieman, G., 2005. Patterns of urban consolidation in Melbourne: planning policy and the growth of medium density housing. Urban Policy and Research 23, 137157.

Catterall, C.P., 1993. The importance of riparian zones to terrestrial wildlife. In: Bunn, S.E., Pusey, B.J., Price, P. (Eds.), Ecology and Management of Riparian Zones in Australia. Land and Water Resources Research and Development Corporation, Canberra, pp. 4152.

Catterall, C.P., Green, R.J., Jones, D.N., 1991. Habitat use by birds across a forest suburb interface in Brisbane: implications for corridors. In: Saunders, D.A., Hobbs, R.J. (Eds.), Nature Conservation 2: The Role of Corridors. Surrey Beatty and Sons, Chipping Norton, pp. 247258.

Chance, J.F., Walsh, J.J., 2006. Urban effects on native avifauna: a review. Landscape and Urban Planning 74, 4669.

Christidis, L., Boles, W.E., 2008. Systematics and Taxonomy of Australian Birds. CSIRO Publishing, Collingwood.

Clergeau, P., Jokimäki, J., Snep, R., 2006a. Using hierarchical levels for urban ecology. Trends in Ecology and Evolution 21, 660661.

Clergeau, P., Croci, S., Jokimäki, J., Kaisanlahti Jokimäki, M. L., Dinetti, M., 2006b. Avifauna homogenization by urbanisation: analysis at different European latitudes. Biological Conservation 127, 336344.

Cornelis, J., Hermy, M., 2004. Biodiversity relationships in urban and suburban parks in Flanders. Landscape and Urban Planning 69, 385401.

Dunford, W., Freemark, K., 2004. Matrix matters: effects of surrounding land uses on forest birds near Ottawa, Canada. Landscape Ecology 20, 497511

Emison, W.B., Beardsell, C.M., Norman, F.I., Loyn, R.H., 1987. Atlas of Victorian Birds. Department of Conservation, Forests and Lands and Royal Australasian Ornithologists Union, Melbourne.

Eppink, F.V., van den Bergh, J.C.J.M., Rietveld, P., 2004. Modelling biodiversity and land use: urban growth, agriculture and nature in a wetland area. Ecological Economics 51, 201216
Fernández Juricic, E., 2000. Bird community composition patterns in urban parks of Madrid: the role of age, size and isolation. Ecological Research 15, 373383.

Fernández Juricic, E., Jokimäki, J., 2001. A habitat island approach to conserving birds in urban landscapes: case studies from southern and northern Europe. Biodiversity and Conservation 10, 20232043

Findlay, S.J., Taylor, M.P., 2006. Why rehabilitate urban river systems? Area 38, 312325.

Fitzsimons, J.A., Palmer, G.C., Antos, M.J., White, J.G., 2003. Refugees and residents: densities and habitat preferences of lorikeets in urban Melbourne. Australian Field Ornithology 20, 27.

Ford, H.A., Barrett, G., 1995. The role of birds and their conservation in agricultural systems. In: Bennett, A., Backhouse, G., Clark, T. (Eds.), People and Nature Conservation: Perspectives on Private Land Use and Endangered Species Recovery. Royal Zoological Society of New South Wales, Mosman, pp. 128135.

Ford, H.A., Noske, S., Bridges, L., 1986. Foraging of birds in eucalypt woodland in north eastern New South Wales. Emu 86, 168179.

Ford, H.A., Paton, D.C., 1986. The Dynamic Partnership: Birds and Plants in Southern Australia. The Flora and Fauna of South Australia Handbooks Committee, Adelaide.

Forman, R.T.T., Galli, A.E., Leck, C.F., 1976. Forest size and avian diversity in New Jersey woodlots with some land use implications. Oecologia 26, 18.

Freemark, K.E., Merriam, H.G., 1986. Importance of area and habitat heterogeneity to bird assemblages in temperate forest fragments. Biological Conservation 36, 115141.

Gilmore, A.M., 1985. The influence of vegetation structure on the density of insectivorous birds. In: Keast, A., Recher, H.F., Ford, H., Saunders, D. (Eds.), Birds of Eucalypt Forests and Woodlands: Ecology, Conservation, Management. Surrey Beatty and Sons, Chipping Norton, pp. 2131

Griffioen, P.A., Clarke, M.F., 2002. Large scale bird movement patterns evident in eastern Australian atlas data. Emu 102, 99 125.

Ihaka, R., Gentleman, R., 1996. R: a language for data analysis and graphics. Journal of Computational and Graphical Statistics 5, 299314.

Jim, C.Y., Chen, S.S., 2003. Comprehensive greenspace planning based on landscape ecology principles in compact Nanjing city, China. Landscape and Urban Planning 65, 95116.

Jokimäki, J., 1999. Occurrence of breeding bird species in urban parks: effects of park structure and broad scale variables. Urban Ecosystems 3, 2134.

Jokimäki, J., Huhta, E., 2000. Artificial nest predation and abundance of birds along an urban gradient. Condor 102, 838 847.

Livingston, M., Shaw, W.W., Harris, L.K., 2003. A model for assessing wildlife habitats in urban landscapes of eastern Pima County, Arizona (USA). Landscape and Urban Planning 64, 131144.

Loyn, R.H., 1985. Ecology, distribution and density of birds in Victorian forests. In: Keast, A., Recher, H.F., Ford, H., Saunders, D. (Eds.), Birds of Eucalypt Forests and Woodlands: Ecology, Conservation, Management. Surrey Beatty and Sons, Chipping Norton, pp. 3346.

Loyn, R.H., 1998. Birds in patches of old growth ash forest, in a matrix of young forest. Pacific Conservation Biology 4, 111121.

Mac Nally, R., 1994. Habitat specific guild structure of forest birds in south eastern Australia: a regional scale perspective. Journal of Animal Ecology 63, 9881001.

Mac Nally, R., 1996. A winter's tale: among year variation in bird community structure in a southeastern Australian forest. Australian Journal of Ecology 20, 442454. 
McIntyre, S., Hobbs, R., 1999. A framework for conceptualizing human effects on landscapes and its relevance to management and research models. Conservation Biology 13, 12821292.

McKinney, M.L., 2006. Urbanization as a major cause of biotic homogenization. Biological Conservation 127, 247260.

Mörtberg, U.M., 2001. bird species in urban forest remnants; landscape and habitat perspectives. Landscape Ecology 16, 193203.

Pacheco, R., Vasconcelos, H.L., 2006. Invertebrate conservation in urban areas: ants in the Brazilian Cerrado. Landscape and Urban Planning 81, 193199.

Palmer, G.C., Bennett, A.F., 2006. Riparian zones provide for distinct bird assemblages in forest mosaics of south east Australia. Biological Conservation 130, 447457.

Park, C.R., Lee, W.S., 2000. Relationship between species composition and area in breeding birds of urban woods in Seoul, Korea. Landscape and Urban Planning 51, 2936.

Parsons, H., French, K., Major, R.E., 2003. The influence of remnant bushland on the composition of suburban bird assemblages in Australia. Landscape and Urban Planning 66, 4356.

Pennington, D.N., Hansel, J., Blair, R.B., 2008. The conservation value of urban riparian areas for landbirds during spring migration: land cover, scale, and vegetation effects. Biological Conservation 141, 12351248.

Pidgeon, A.M., Radeloff, V.C., Flather, C.H., Lepczyk, C.A., Clayton, M.K., Hawbaker, T.J., Hammer, R.B., 2007. Associations of forest bird species richness with housing and landscape patterns across the USA. Ecological Applications 17, 19892010.

Platt, A., Lill, A., 2006. Composition and conservation value of bird assemblages of urban 'habitat islands': do pedestrian traffic and landscape variables exert an influence? Urban Ecosystems 9, 8397.

Recher, H.F., 2004. The Kings Park avifauna: keeping birds in the city. In: Lunney, D., Burgin, S. (Eds.), Urban Wildlife: More than Meets the Eye. Royal Zoological Society of New South Wales, Mosman, pp. 820.

Recher, H.F., Holmes, R.T., 1985. Foraging ecology, and seasonal patterns of abundance in a forest avifauna. In: Keast, A.,
Recher, H.F., Ford, H., Saunders, D. (Eds.), Birds of Eucalypt Forests and Woodlands: Ecology Conservation Management. Springer, Berlin, pp. 7996.

Rottenborn, S.C., 1999. Predicting the impacts of urbanization on riparian bird communities. Biological Conservation 88, 289 299.

Saunders, D.A., Hobbs, R.J., Margules, C.R., 1991. Biological consequences of ecosystem fragmentation: a review. Conservation Biology 5, 1832.

Savard, J. P.L., Clergeau, P., Mennechez, G., 2000. Biodiversity concepts and urban ecosystems. Landscape and Urban Planning 48, 131142.

Smith, P.G.R., 2007. Characteristics of urban natural areas influencing winter bird use in southern Ontario, Canada. Environmental Management 39, 338352.

Smith, J., Lill, A., 2008. Importance of eucalyptus in exploitation of urban parks by Rainbow and Musk Lorikeets. Emu 108, 187 195.

Tilghman, N.G., 1987. Characteristics of urban woodlands affecting breeding bird diversity and abundance. Landscape and Urban Planning 14, 481495.

Tzaros, C.L., 2001. Importance of riparian vegetation to terrestrial avifauna along the Murray River, southeastern Australia. M.Sc. Thesis. Deakin University, Melbourne.

Walsh, C., Mac Nally, R., 2003. The hier.part Package, Version 0.5 1. Hierarchical Partitioning. Documentation for $R$ (R project for statistical computing). [http://cran.r project.org/].

White, J.G., Antos, M.J., Fitzsimons, J.A., Palmer, G.C., 2005. Non uniform bird assemblages in urban environments: the influence of streetscape vegetation. Landscape and Urban Planning 71, 123135.

Whited, D., Galatowitsch, S., Tester, J.R., Schik, K., Rehtinen, R., Husveth, J., 2000. The importance of local and regional factors in predicting effective conservation: planning strategies for wetland bird communities in agricultural and urban landscapes. Landscape and Urban Planning 49, 4965.

Willson, M.F., 1974. Avian community organization and habitat structure. Ecology 55, 10171029. 